\title{
Refuerzo externo a cortante con láminas de CFRP en elementos de hormigón armado
}

\author{
Shear strengthening of reinforced concrete members \\ with CFRP sheets
}

\author{
A. Alzate $^{(*, * *)}$, A. Arteaga(*), A. de Diego(*), D. Cisneros $(*)$, R. Perera(***)
}

Recepción/Received: 14-XI-11

Aceptación/Accepted: $20-\mathrm{II}-12$

Publicado online/Online publishing: 21-III-12

\section{RESUMEN}

La técnica de refuerzo externo a cortante en elementos de HA con polímeros armados con fibra, conocida como EBR-FRP por sus siglas en inglés, se ha ganado un puesto importante en el área de reparación y rehabilitación de estructuras gracias a las excelentes propiedades mecánicas de estos materiales, y sus enormes ventajas respecto a otras técnicas. Sin embargo, debido a que su uso es relativamente reciente en la ingeniería civil, existen pocas recomendaciones o guías que consideren esta técnica. Las guías de cálculo existentes muestran un procedimiento bien definido y aceptado con respecto al cálculo a flexión, sin embargo, los modelos de cálculo a cortante resultan ser altamente variados y controvertidos. Este documento muestra el enfoque actual para el cálculo de esfuerzos cortantes y sus limitaciones, así como el proceso de una investigación experimental sobre vigas de hormigón armado reforzadas externamente con tejido unidireccional de CFRP.

Palabras clave: polímeros armados con fibras (FRP); hormigón; refuerzo a cortante; estudio experimental.

\section{SUMMARY}

In light of their excellent mechanical properties and other advantages over conventional systems for repairing and rehabilitating structures, fibre-reinforced polymers (FRPS) are commonly used to enhance the shear strength of $R C$ members. Because of the relatively recent application of the technique in civil engineering, however, it is addressed in very few recommendations or guides. While the design guides in place contain a single, well defined and generaIly accepted procedure for calculating bending moments, they collectively propose a wide variety of numerical models for shear, none of which is universally acknowledged. The present article focuses on the calculation of ultimate shear strength and describes an experimental study in that context conducted on reinforced concrete beams retrofitted with unidirectional carbon fibre reinforced polymer (CFRP) fabric.

Keywords: fibre-reinforced polymers (FRP); concrete; shear strengthening; experimental study.

(*) Instituto de Ciencias de la Construcción Eduardo Torroja (IETcc-CSIC) (Madrid, España).

(**) Universidad de Medellín (Medellín, Colombia).

(***) Universidad Politécnica de Madrid (Madrid, España).

Persona de contacto / Corresponding author. alalzate@udem.edu.co 


\section{INTRODUCCIÓN}

El uso comercial de los materiales compuestos formados por polímeros armados con fibra (Fibre Reinforced Polymer - FRP) se inició hace casi 50 años, originariamente en la industria aeronáutica, naval y automovilística, y muy posteriormente en la ingeniería civil y la edificación. En la actualidad, en el campo de la construcción, la reparación y rehabilitación de estructuras representa un campo en crecimiento y gran interés, ligado a la necesidad de preservar estructuras bien por criterios de conservación del patrimonio histórico, o en general para el mantenimiento o incremento de la vida útil de las estructuras. Los FRP han encontrado un campo óptimo de desarrollo en la reparación y refuerzo de estructuras frente a técnicas más tradicionales.

La técnica del refuerzo con FRP está consolidada. Las investigaciones sobre el tema se iniciaron en la década de los 90, donde los estudios realizados muestran un procedimiento bien definido y aceptado en lo referente al cálculo a flexión y confinamiento de pilares. Aunque en menor medida, también el refuerzo frente a esfuerzo cortante ha sido estudiado y se ha puesto de manifiesto su eficacia para incrementar la capacidad última, aunque no existan aún modelos de cálculo unánimemente aceptados. Los modelos teóricos propuestos para el dimensionado del refuerzo a esfuerzo cortante de estructuras de HA han sido diferentes y controvertidos. Existen modelos complejos que explican el comportamiento a esfuerzo cortante, pero no tienen transposición directa a fórmulas de cálculo. Cuando además se añade un refuerzo externo de FRP los modelos son aún más complejos, evidentemente.

Las guías y recomendaciones existentes (1-5) proponen calcular la capacidad resistente total de la sección sumando la contribución del HA (dada, en general, como la suma de la debida al hormigón y armadura pasiva) y la dada por el refuerzo externo de FRP. La contribución del HA está dada en códigos bien establecidos mientras que para la del FRP las distintas normativas dan distintos procedimientos. Algunas expresiones propuestas son empíricas mientras que otras adaptan al refuerzo de cortante los modelos de biela y tirante utilizados para el HA.

En los primeros estudios Triantafillou (6) mostró que el refuerzo transversal de FRP podía aumentar la capacidad a cortante del elemento reforzado y propuso un modelo obtenido mediante un ajuste de datos experimentales, donde la contribución del FRP es limitada por la deformación efectiva en el material compuesto. Más adelante, Khalifa et al. (7) modificaría el modelo de Triantafillou introduciendo una limitación en la deformación debida a la abertura de la fisura y a la pérdida del engranamiento de áridos. Estos estudios fueron seguidos por los realizados

\section{INTRODUCTION}

While the aeronautic, naval and automobile industries first began to use fibre-reinforced polymer or FRP composite materials commercially 50 years ago, their application in civil engineering and building is much more recent. Nonetheless, structural repair and rehabilitation constitutes a field of growing interest in construction today, in light of the need to conserve the historic heritage or simply maintain or lengthen the service life of structures in general. FRPs have proven to be an optimal solution in structural repair and strengthening, with many advantages over more traditional techniques.

FRP strengthening of reinforced concrete structures is a consolidated technique. The earliest research on the subject was conducted in the nineteen nineties. Those studies culminated in a well defined and widely accepted procedure for calculating bending strength and column confinement. Shear strengthening has also been studied, albeit less extensively, and its effectiveness in raising ultimate capacity has been proven. Nonetheless, no unanimously accepted numerical models have yet been developed. A number of theoretical models have been put forward for dimensioning shear strengthening in RC structures, but none has been generally accepted. Several complex approaches explain behaviour under shear stress, but have not been directly transposed into mathematical formulas. Moreover, factoring in the effect of externally bonded FRP obviously adds to the complexity of such models.

The existing guides and recommendations (1-5) calculate total section capacity by adding the contributions made by the $R C$ (taken, as a rule, to be the sum of the strength attributed to the concrete and the passive reinforcement) and the retrofitted FRP. While the $R C$ contribution is tabulated in well established codes, different standards recommend different procedures for the FRP. Some of the expressions are empirical while others adapt the strut and tie models used in RC design to shear strengthening.

In the earliest studies, Triantafillou (6) showed that transverse FRP reinforcement could raise the shear strength of the member involved and proposed a model obtained by fitting experimental data in which the FRP contribution to strength was limited by the effective strain in the composite material. Later, the Triantafillou model was modified by Khalifa et al. (7), who limited that contribution to control crack width and the loss of aggregate interlock. These efforts were followed by studies by Teng et al. (8) and Chen and Teng (9), who related the FRP contribution to 
por Teng et al. (8) y Chen y Teng (9) quienes relacionaron la contribución a la capacidad a cortante del FRP a la resistencia de pegado en una fisura intermedia. Deniaud y Cheng (10) mostraron a través de ensayos que no siempre hay interacción completa entre el FRP y los estribos de acero y establecieron que las deformaciones del FRP son uniformemente distribuidas entre las fibras que cruzan la fisura crítica y desarrollaron un modelo de cálculo basado en el mecanismo de fallo observado en los ensayos de los especímenes. Un modelo más refinado fue propuesto más tarde por Deniaud y Cheng (11). Pellegrino y Modena (12) recomendaron un factor de reducción para la relación entre la deformación efectiva y la deformación última, y desarrollaron un modelo siguiendo un acercamiento al modelo de la celosía. Una cantidad importante de trabajos han sido publicados en los últimos años (13-21), algunos de los cuales han servido de base para guías de cálculo y normativas.

\section{MÉTODOS DE REFUERZO DE ELEMENTOS A CORTANTE}

En general, el FRP utilizado en el refuerzo a cortante está formado por fibras de carbono, con mayor resistencia y rigidez que compensan su mayor precio, y un adhesivo de tipo epoxídico, existiendo diversas técnicas:

- Sistema de laminado: consiste en la colocación externa de una lámina recta o en $L$ prefabricada con dimensiones típicas de $1,2 \mathrm{~mm}$ de espesor por un ancho entre 50 y $100 \mathrm{~mm}$ adherida al elemento con deficiencia a cortante.

- Sistema con tejido unidireccional: es un sistema in-situ, donde el FRP se forma a partir de un tejido unidireccional de fibras y una resina tipo epoxi, mediante un proceso manual de impregnación y moldeo directamente sobre el elemento a reforzar. Este tejido normalmente se encuentran en el mercado con un ancho entre 200 y $400 \mathrm{~mm}$ y un peso de fibra entre 200 y $600 \mathrm{~g} / \mathrm{m}^{2}$. Debido a la capacidad que tiene este sistema para adaptarse a las formas es el más usado como refuerzo a cortante.

- Sistema NSM: este sistema consiste en insertar el refuerzo, generalmente de CFRP (bien en forma de láminas con un espesor de unos $2 \mathrm{~mm}$ y un ancho de 15-20 mm o barras de diámetro 6 u $8 \mathrm{~mm}$ ) dentro de una ranura hecha en el recubrimiento de hormigón que se rellena de resina.

\section{RESISTENCIA A CORTANTE}

Las guías y recomendaciones (1-5) proponen calcular la capacidad resistente a cortante de los elementos de HA reforzados con FRP, añadiéndole a la contribución del HA, shear strength to the bond strength in an intermediate crack. Deniaud and Cheng's (10) experiments showed that FRP and steel stirrups do not always interact fully and that strain is evenly distributed among the fibres in the FRP crossed by the critical crack. They consequently developed a numerical model based on the failure mechanism observed in their trials. These same authors (11) later refined their model. Pellegrino and Modena (12) recommended a reduction factor for the ratio between the effective and ultimate strain and developed a model based on the truss analogy approach. A significant number of papers have been published on the subject in recent years (13-21), some of which have served as a basis for engineering guides and codes.

\section{METHODS FOR SHEAR STRENGTHENING MEMBERS}

As a rule, the FRP used for shear strengthening consists of carbon fibres, whose high strength and stiffness justify their cost, and an epoxy adhesive. Several techniques are in place.

- Plates: this system consists of externally bonding a straight or L-shaped sheet of FRP, typically $1.2 \mathrm{~mm}$ thick and from 50 to $100 \mathrm{~mm}$ wide, to the sheardeficient member.

- Unidirectional fabric: in this in situ system the FRP consists of a unidirectional fibre fabric manually impregnated with epoxy resin and applied directly to the member to be strengthened. This fabric is generally marketed in widths of 200 and $400 \mathrm{~mm}$, with a fibre density of 200 to $600 \mathrm{~g} / \mathrm{m}^{2}$. Because of the ease with which it can be adapted to different shapes, it is the system most commonly used in shear strengthening.

- NSM (near-surface mounted) FRP: in this system the material, usually CFRP (in $2 \mathrm{~mm}$ thick, $15-20 \mathrm{~mm}$ wide strips or 6- to 8- $\mathrm{mm}$ diameter rods), is fitted into a resin-filled groove made in the concrete cover.

\section{SHEAR STRENGTH}

The existing guides and codes (1-5) recommend calculating the shear capacity of FRP-strengthened RC members by adding the contributions made by the externally 
en general como la suma del hormigón y de la armadura pasiva, la dada por el refuerzo externo, aunque en este caso sea más dudosa la adecuación del modelo. Así [1]: bonded composite and the RC, i.e., the sum of the strength attributable to the concrete and to the passive reinforcement, although in this case the suitability of the model is questionable. Hence [1]:

$$
V=V_{\mathrm{c}}+V_{\mathrm{s}}+V_{\mathrm{f}}
$$

Donde $V_{c}$ es el aporte hecho por el hormigón, $V_{S}$ el hecho por los cercos internos y $V_{f}$ el hecho por el FRP. La contribución del hormigón y de los cercos se calcula según las normativas de hormigón armado (22-24) con lo que sólo nos quedaría conocer la capacidad aportada por el FRP, para lo cual es necesario estudiar otras características, como los esquemas de refuerzo y los modos de fallo. El Eurocódigo 2 (22), presenta un enfoque diferente para el cálculo del HA: se asume que el esfuerzo cortante debe ser resistido completamente por la armadura transversal en caso de que la resistencia aportada por el hormigón no sea suficiente. La contribución del hormigón y de los cercos debe hacerse, en principio, por medio de la normativa en vigor y por tanto, el tema que debe definirse ahora es cómo calcular la contribución del refuerzo externo de FRP.

Los esquemas de refuerzo externo con FRP más habituales se pueden agrupar en tres tipos: pegado lateral, configuración en $U$ y sección completamente envuelta (Figura 1). Se puede variar la orientación de las fibras del FRP y la separación entre los elementos de refuerzo. where $V_{G} V_{s}$ and $V_{f}$ are the contributions made by the concrete, inner tie bars and FRP, respectively. Given that the contribution attributed to the concrete and tie bars can be calculated as specified in the standards on reinforced concrete (22-24), all that actually needs to be calculated is the strength afforded by the FRP. This calls for studying other characteristics, such as strengthening schemes and failure modes. Eurocode 2 (22) takes a different approach to $R C$ calculation: it assumes that if concrete strength is insufficient, the shear stress must be resisted in its entirety by the transverse reinforcement. The contribution made by the concrete and the inner ties should be calculated as specified in the existing codes. Consequently, the question to be defined here is how to calculate the shear strength attributable to the FRP.

FRP strengthening is positioned according to essentially one of three patterns: side bonding, U-jacketing or complete wrapping (Figure 1). The angle of the FRP fibres with respect to the member as well as the spacing between strengthening elements may vary in all three.

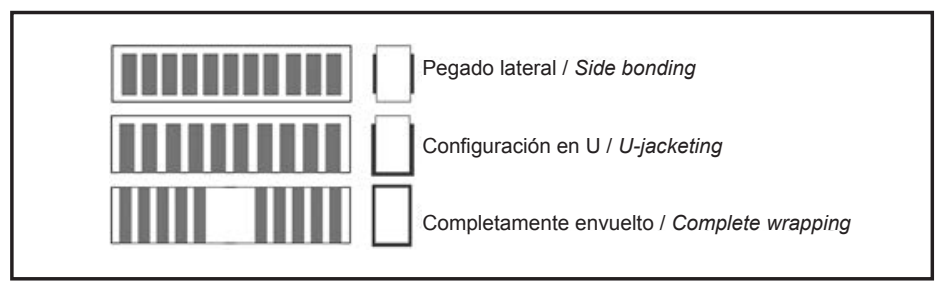

Figura 1. Esquemas de refuerzo de la viga reforzada. Figure 1. FRP strengthening patterns.

La forma de rotura depende esencialmente de la longitud de adherencia, de la separación entre refuerzos y de la resistencia de pegado entre en FRP y el hormigón. Los modos de fallo posibles se pueden agrupar como:

- Fallo a cortante con rotura del FRP.

- Fallo a cortante sin rotura del FRP: por aplastamiento de las bielas de compresión o por que la fisura de cortante encuentra camino entre las separaciones del refuerzo.

- Fallo por delaminación:

- Desprendimiento en la interfaz FRP - adhesivo.

- Desprendimiento en la interfaz adhesivo - hormigón.

- Desgarro del recubrimiento de hormigón.
The failure model depends essentially on bond length, the spacing between strengthening elements and the strength of the bond between the FRP and the concrete. The possible failure modes are:

- Shear failure, with rupture of the FRP.

- Shear failure, without rupture of the FRP: due to collapse of the compression struts or because the shear crack finds a pathway across the spacing between strengthening elements.

- Debonding:

- Separation at the FRP-adhesive interface.

- Separation of the adhesive-concrete interface.

- Detachment of the concrete cover. 
Una vez conocidos los modos de fallo en elementos de HA reforzados con FRP e interpretando los esquemas de refuerzo que se pueden utilizar, varios autores han propuestos diferentes modelos de cálculo para predecir la resistencia aportada por el FRP. Algunas de estas expresiones propuestas son empíricas mientras que otras son más de carácter analítico, tratando de adaptar al refuerzo de cortante los modelos de biela y tirante utilizados para el HA. Los modelos de cálculo basados en el acercamiento de la analogía de la celosía, han demostrado tener las mejores predicciones en el valor del aporte a cortante hecho por el FRP, debido a la calibración de las deformaciones efectivas a través de ensayos experimentales (25). Algunos de los modelos más utilizados en el medio, tales como el fib (1), Teng et al. (8), CNR (3) y ACI (5), están basados en dicho acercamiento y su principal diferencia radica en el cálculo de las deformaciones efectivas y la altura efectiva tomada para el FRP. Dichos modelos, serán objeto de comparación en este trabajo.

\section{PROGRAMA EXPERIMENTAL}

Son dos los problemas principales aún no resueltos por los modelos de cálculo en las guías de diseño (1-5): uno es cuál será la tensión efectiva máxima que soporte el refuerzo externo antes de su rotura o despegue y el otro, la interacción entre el refuerzo externo y el interno: la presencia de ambos puede impedir que ambos alcancen su máxima capacidad.

Con idea de aportar luces en estos temas se ha desarrollado un estudio que incluía un programa experimental que comprende el diseño, fabricación y rotura de 16 vigas de HA reforzadas con tejido de CFRP pegado in-situ. Se han considerado como variables únicamente: la configuración del refuerzo (en U o completamente envuelto $(\mathrm{W})$ ), la orientación de las fibras de FRP con respecto al eje longitudinal de la viga $\left(90^{\circ}\right.$ ó $\left.45^{\circ}\right)$, con espaciamiento entre las bandas de $200 \mathrm{~mm}$ (S) o continuo (C) y dos gramajes de tejido (300 ó $530 \mathrm{~g} / \mathrm{m}^{2}$ ). El programa se resume en la Tabla 1 .
Based on the definition of the failure modes in FRPretrofitted $R C$ members and the strengthening patterns that can be used, a number of authors have proposed numerical calculations to predict the portion of shear strength attributable to these composites. Some of the expressions are empirical while others, more analytical, attempt to adapt the strut and tie models used in RC design to shear strengthening. The numerical models based on the truss analogy approach have proven to provide the best predictions for the value of the FRP contribution to shear strength, because effective strain is calibrated on the grounds of experimental evidence (25). Some of the most widely used models, including fib (1), Teng et al. (8), CNR (3) and ACI (5), are based on that approach and differ primarily in the way they calculate effective strain and the effective height used for the FRP. These are the models that are compared in the present study.

\section{EXPERIMENTAL}

Two major problems remain unsolved by the theoretical models set out in the existing design guides (1-5). Specifically, they fail to determine, on the one hand, the effective maximum stress withstood by the externally bonded composite before failure or detachment, and on the other, the interaction between the internal steel and the external composite, whose joint presence may hinder either from reaching its maximum strength.

The present study, conducted to shed light on these subjects, included an experimental programme covering the design, manufacture and failure testing of $16 R C$ beams with CFRP fabric externally bonded in situ. The sole variables considered were the strengthening pattern (U-jacketing $(U)$ or complete wrapping $(W)$ ), the angle of the FRP fibres with respect to the longitudinal axis of the beam (90 or 450), the existence (S) or no (C) of $200 \mathrm{~mm}$ spacing between the sheets, and fabric density (300 or $\left.530 \mathrm{~g} / \mathrm{m}^{2}\right)$. The programme is summarised in Table 1.

Tabla 1 / Table 1

Programa de ensayos.

Testing programme.

\begin{tabular}{|c|c|c|c|c|c|}
\hline Series & $\begin{array}{c}\text { Configuración / } \\
\text { Pattern }\end{array}$ & $\begin{array}{l}\text { Orientación de la fibra } \\
\text { / Fibre angle }\left[{ }^{\circ}\right]\end{array}$ & $\begin{array}{l}\text { Cantidad de fibra / } \\
\text { Fibre density }\left[\mathrm{g} / \mathrm{m}^{2}\right]\end{array}$ & $\begin{array}{l}\text { Espaciamiento / } \\
\text { Spacing [mm] }\end{array}$ & $\begin{array}{l}\text { Número de vigas I } \\
\text { Number of beams }\end{array}$ \\
\hline Control & - & - & 0 & - & 1 \\
\hline U90C5 & $\mathrm{U}$ & 90 & 530 & 0 & 2 \\
\hline U90S5 & $\mathrm{U}$ & 90 & 530 & 200 & 2 \\
\hline U45S5 & $\mathrm{U}$ & 45 & 530 & 200 & 1 \\
\hline W90S5 & $W$ & 90 & 530 & 200 & 1 \\
\hline U90C3 & $\mathrm{U}$ & 90 & 300 & 0 & 2 \\
\hline U90S3 & $\mathrm{U}$ & 90 & 300 & 200 & 3 \\
\hline U45S3 & $\mathrm{U}$ & 45 & 300 & 200 & 2 \\
\hline W90S3 & W & 90 & 300 & 200 & 2 \\
\hline
\end{tabular}




\subsection{Descripción de las probetas}

Cada viga cuenta con una longitud total de $4.500 \mathrm{~mm}$ y sección transversal de $420 \mathrm{~mm}$ de canto por $250 \mathrm{~mm}$ de ancho. El acero de armado longitudinal con límite elástico (fy) de $500 \mathrm{MPa}$ consta en su parte inferior de 6 barras corrugadas de diámetro nominal $20 \mathrm{~mm}$ dispuesto en dos capas ( 4 barras en la primera y 2 en la segunda) y en la parte superior de 2 barras de diámetro nominal de $10 \mathrm{~mm}$. El refuerzo transversal a cortante con un límite elástico (fy) de $500 \mathrm{MPa}$, está compuesto por estribos cerrados de diámetro nominal de $8 \mathrm{~mm}$ espaciados cada $380 \mathrm{~mm}$ (Figura 2).

Una vez las vigas han pasado su etapa de curado se aplica el refuerzo de FRP, el cual está compuesto por tejido unidireccional de fibra de carbono de ancho de $300 \mathrm{~mm}$, el cual se adhiere a la viga mediante la resina epoxi sugerida por el distribuidor, usando un procedimiento manual mediante la técnica de impregnación, moldeo y posterior curado durante 7 días. En la Tabla 2 se presenta las propiedades suministradas por los distribuidores para la fibra de carbono y su respectiva resina.

\subsection{Specimen description}

All the beams measured $4500 \mathrm{~mm}$ long with a section measuring $420 \mathrm{~mm}$ deep by $250 \mathrm{~mm}$ wide. The 500 MPa (yield strength: fy) longitudinal steel consisted of six layered (four plus two) $20 \mathrm{~mm}$ diameter bottom ribbed bars and two $10 \mathrm{~mm}$ diameter top bars. The shear reinforcement, likewise made of 500 MPa steel, consisted of $8 \mathrm{~mm}$ ties or closed stirrups spaced at $380 \mathrm{~mm}$ intervals (Figure 2).

After the beams had been fully cured, they were manually retrofitted with $300 \mathrm{~mm}$ wide unidirectional carbon fibre fabric impregnated with the epoxy resin recommended by the distributor. The trials were conducted 7 days after application of the composite. Table 2 lists the properties of the carbon fibre and resin provided by the distributors. Before applying the FRP, the surface was sand-blasted to remove the outer layer of cement and then brushed clean to ensure a good bond between the concrete and the fabric. In addition, to prevent premature failure of the FRP, the beam corners were rounded during casting by placing $25 \mathrm{~mm}$ radius concave wooden chocks in the forms.

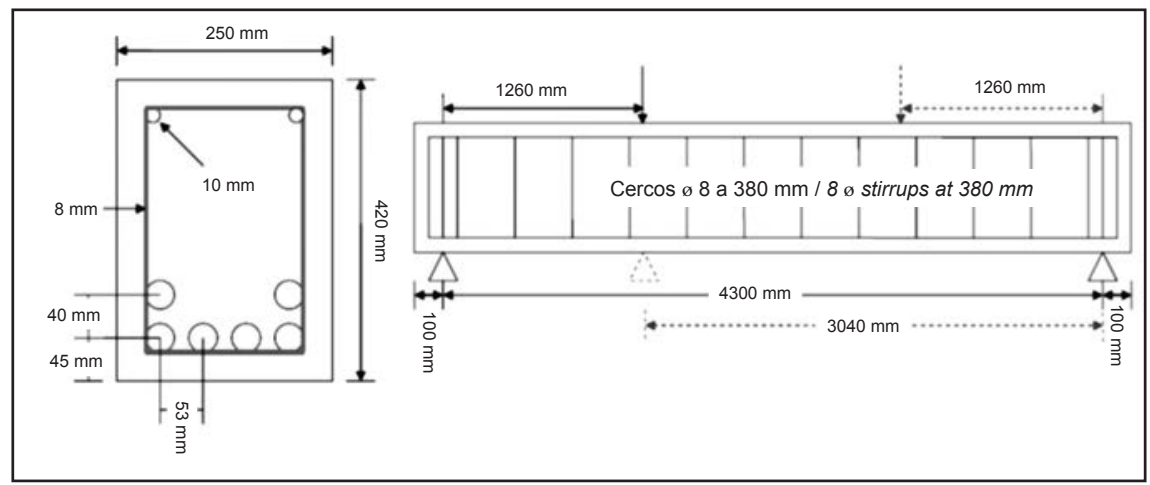

Figura 2. Geometría de las vigas y esquema de ensayo. Figure 2. Beam geometry and test set-up.

Tabla 2 / Table 2

Propiedades de la fibra de carbono y la resina epoxi. Carbon fibre and epoxy resin. Properties.

\begin{tabular}{|c|c|c|c|c|}
\hline & $\begin{array}{c}\text { Espesor / } \\
\text { Thickness [mm] }\end{array}$ & $\begin{array}{c}\text { Resist. a tracción / } \\
\text { Tensile strength [MPa] }\end{array}$ & $\begin{array}{c}\text { Módulo de Young / Young's } \\
\text { modulus [MPa] }\end{array}$ & $\begin{array}{c}\text { Deformación máx. I } \\
\text { Max. strain [\%] }\end{array}$ \\
\hline MBrace CF 130 & 0.165 & 3800 & 240000 & 1.55 \\
\hline SikaWrap-530C & 0.293 & 4000 & 240000 & 1.5 \\
\hline MBrace RESIN 55 & - & $17^{*}$ & $2800^{* *}$ & - \\
\hline Sikadur-300 & - & 45 & 3500 & - \\
\hline
\end{tabular}

* Ensayo de Pull-out (UNE-EN 12188). ** Módulo de Young a compresión. / * Pull-out test (Spanish and European standard UNE-EN 12188). ** For compressive strength. 


\subsection{Instrumentación y descripción de los ensayos}

Con el fin de medir la interacción existente entre el FRP y los estribos de acero, cada viga esta instrumentada con bandas extensométricas colocadas en los estribos (2 por estribo) a la mitad de su altura, y bandas extensométricas colocadas sobre el tejido de FRP coincidiendo en lo posible con la posición de las bandas en los estribos. La Figura 3 muestra la disposición de las bandas extensométricas, que se repite en las dos caras de la viga. El desplazamiento vertical en el centro de la viga se mide con un LVDT.

La viga descansa en dos soportes a $100 \mathrm{~mm}$ del borde sobre un palastro de $80 \mathrm{~mm}$ y rodillos de acero. La carga es aplicada con un gato hidráulico de $500 \mathrm{kN}$ repartida en todo el ancho con un perfil metálico colocado sobre el punto de aplicación sobre una base de escayola (Figura 4). Por limitación del equipo de carga, los ensayos tuvieron que realizarse con control por carga a una velocidad de 0,30 kN/s, donde la aplicación de la misma se hizo de forma continua hasta la rotura. El desplazamiento en el centro de vano y las deformaciones en las bandas extensométricas se registraron de forma continua mediante ordenador a través un datalogger. Durante los ensayos, salvo la viga de control, no era posible controlar la fisuración por la presencia del refuerzo. El perfil de fisuración se determinó a posteriori, retirando el refuerzo al finalizar el ensayo.

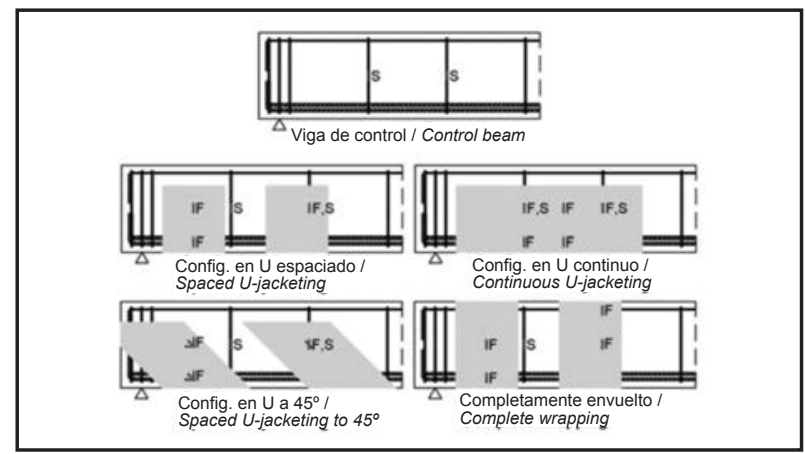

Figura 3. Posición de las bandas ( $\mathrm{F}$ en FRP, $\mathrm{S}$ en cercos). Figure 3. Strain gauges positions ( $F$, on FRP; $S$ on stirrups).

Sobre cada una de las vigas, se realizaron dos ensayos (ver Figura 2):

- Viga larga: el primer ensayo se realiza sobre el total de la viga con una luz de 4.300 mm, en la cual se coloca una sola carga a una distancia de un apoyo igual a tres veces el canto total.

- Viga corta: una vez realizado este ensayo, se mueve el apoyo junto al que se ha producido el fallo al punto donde estaba situada la carga en el primer ensayo y se aplica la carga a una distancia igual a tres veces el canto del apoyo en el extremo opuesto.

\subsection{Instrumentation and trial description}

Strain gauges (two per stirrup) were installed at midheight on each stirrup and at a matching height on the $F R P$ fabric to measure the interaction between the FRP and the steel stirrups. Figure 3 shows the position of the gauges, which were placed on both sides of the beam. Vertical displacement at mid-span was measured with a linear variable differential transformer (LVDT).

The beams rested on steel rollers positioned at $100 \mathrm{~mm}$ from either end and set on $80 \mathrm{~mm}$ sheet steel that covered the concrete supports. The load, applied by a $500 \mathrm{kN}$ hydraulic jack, was distributed across the entire width with a steel shape lying on a plaster base and positioned underneath the jack (Figure 4). Due to test facility limitations, the tests were load-controlled. A steady loading rate of $0.30 \mathrm{kN} / \mathrm{s}$ was maintained through failure. Mid-span displacement and the strain detected by the strain gauges were logged continuously by a datalogger and recorded on a computer. Cracking was monitored during the trials in the control beam. In all other cases, the crack profile had to be determined post-trial after removal of the FRP fabric.

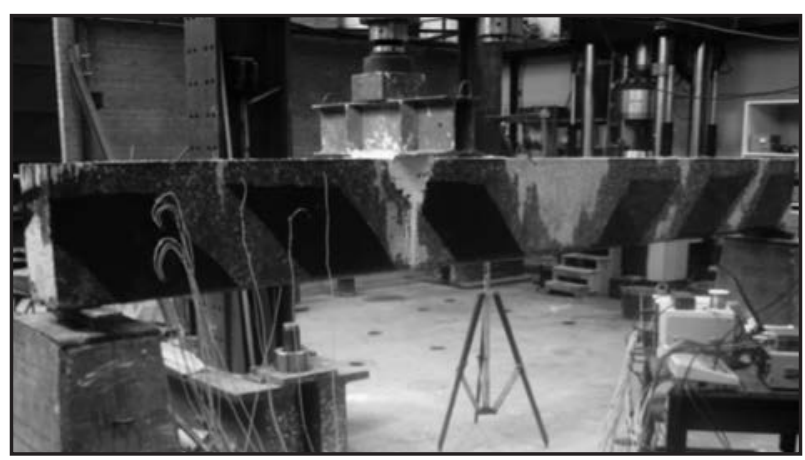

Figura 4. Disposición del ensayo. Figure 4. Test set-up.

Two trials were conducted on each beam (see Figure 2).

- Long span: the first trial was conducted on the entire $4300 \mathrm{~mm}$ span, applying a single load at a distance from one of the supports equal to three times the total depth.

- Short span: the support closest to the loading point in the preceding trial was moved to support the broken end of the beam, which was again loaded, now at a distance from the opposite end equal to three times the depth. 


\section{RESULTADOS}

En la Tabla 3, se resumen la resistencia a compresión del hormigón, la resistencia a cortante para cada viga, la resistencia media y su relación con la viga de control. De dicha tabla se deduce, en primer lugar, la amplia dispersión de los valores obtenidos entre los dos ensayos en la misma viga, sin embargo, debe observarse que, a pesar de dicha dispersión, los valores promedios de todos los ensayos cortos y largos son prácticamente idénticos. Por tanto, debe considerarse esa variación debida a la aleatoriedad intrínseca y no se distingue en adelante los dos tipos de ensayos.

\section{RESULTS}

Table 3 summarises concrete compressive strength, shear strength, mean strength and the mean strength/control beam strength ratio, beam-by-beam. The data reveal substantial differences between the values for the two trials in any one beam. Despite that scatter, however, the mean values for the short and long span trials as a whole were practically identical. The variation was consequently regarded to be due to the randomness inherent in such tests and no distinction is drawn hereafter between them.

Tabla 3 / Table 3

Resistencia máxima a cortante.

Maximum shear strength.

\begin{tabular}{|c|c|c|c|c|c|}
\hline \multirow{2}{*}{ Viga / Beam } & \multirow{2}{*}{$\underset{[\mathrm{MPa}]}{f_{\mathrm{cm}}}$} & \multicolumn{2}{|c|}{ Cortante de rotura / Ultimate shear $[\mathrm{kN}]$} & \multirow{2}{*}{$\begin{array}{l}\text { Promedio I } \\
\text { Mean [kN] }\end{array}$} & \multirow{2}{*}{$\begin{array}{l}\text { Prom./Refer. I } \\
\text { Mean/Ctrl. }\end{array}$} \\
\hline & & Vano largo / Long span & $\begin{array}{l}\text { Vano corto I } \\
\text { Short span }\end{array}$ & & \\
\hline Control & 36.95 & 148.99 & 158.24 & 153,61 & 1,00 \\
\hline U90S5-a & 36.95 & 246.73 & 218.14 & 232.44 & 1.51 \\
\hline U90S5-b & 28.01 & 235.92 & 225.62 & 230.77 & 1.50 \\
\hline U90C5-a & 24.47 & 217.04 & 194.49 & 205.76 & 1.34 \\
\hline U90C5-b & 22.64 & 243.27 & 221.93 & 232.60 & 1.51 \\
\hline U45S5 & 30.67 & 206.22 & 221.4 & 213.81 & 1.39 \\
\hline W90S5 & 24.47 & 276.21 & 374.28 & 325.25 & 2.12 \\
\hline U90S3-a & 20.5 & 207.43 & 195.64 & 201.53 & 1.31 \\
\hline U90S3-b & 22.58 & 203.61 & 223.86 & 213.74 & 1.39 \\
\hline U90S3-c & 28.01 & 231.82 & 179.25 & 205.53 & 1.34 \\
\hline U90C3-a & 30.2 & 208.84 & 215.43 & 212.14 & 1.38 \\
\hline U90C3-b & 30.2 & 201.77 & 203.95 & 202.86 & 1.32 \\
\hline U45S3-a & 20.5 & 189.61 & 198.8 & 194.21 & 1.26 \\
\hline U45S3-b & 30.67 & 211.03 & 207.64 & 209.34 & 1.36 \\
\hline W90S3-a & 22.64 & 284.34 & 276.62 & 316.39 & 2.06 \\
\hline W90S3-b & 22.58 & 311.42 & 321.35 & 280.48 & 1.83 \\
\hline Promedio / Mean & & 226.52 & 227.29 & & \\
\hline
\end{tabular}

Como era de esperar, el refuerzo externo a cortante con FRP mejora la capacidad de la viga para resistir estos esfuerzos. En este programa de ensayos, donde la cuantía de acero transversal es mínima, se produce un aumento que varía entre un $30 \%$ y un $112 \%$ dependiendo de la configuración y cantidad de refuerzo de FRP (se debe tener en cuenta que la resistencia del hormigón es mayor en la viga de control). El fallo ocurre por delaminación con desprendimiento de la capa superficial de hormigón en las vigas con configuración en $U$ y en las vigas con la sección completamente envuelta el fallo ocurre por rotura de la lámina en unos casos o por flexión sin influencia del cortante.

En la Figura 5 se presentan, separadas por gramaje, las gráficas cortante vs. deflexión en el centro de vano para los ensayos de viga larga (las curvas de vigas cortas son similares). No se observa un aumento en la rigidez de las vigas reforzadas con respecto a la viga de control. No se presenta aumento significativo de carga entre las vigas
As expected, externally bonded FRP improved beam shear capacity. In the present study, in which the transverse steel ratio was very small, the increase ranged from 30 to $112 \%$ depending on the amount of fibre and application pattern. Note that concrete strength was greater in the control beam. Failure occurred in the U-jacketed beams due to debonding with detachment of the outer layer of concrete, and in the completely wrapped beams, to composite failure or to bending failure in which shear played no part.

Figure 5 shows the mid-span shear vs deflection graphs for the long span trials (the short span curves were similar) by fabric density. Stiffness was not observed to be greater in the strengthened beams than in the control. No significant differences were found in ultimate load between the U90S, U90C and U45S patterns for the same fibre density, and 
con configuración U90S, U90C y U45S con igual cantidad de fibra, y un leve incremento que oscila entre un $6 \%$ y un $12 \%$ entre esas mismas vigas con mayor cantidad de fibra. Particularmente las vigas con la sección completamente envuelta fueron las de mejor comportamiento, comparadas tanto con la viga patrón como con otras configuraciones de refuerzo. Después del punto pico de cortante máximo, la curvas cortante-deflexión para las vigas reforzadas en configuración $U$ muestran una rama descendente con caída abrupta poniendo en evidencia un tipo de fallo frágil, en contraste con las curvas para las vigas reforzadas con la sección completamente envuelta, donde se presenta un comportamiento más dúctil. only slightly greater differences, of 6 or $12 \%$, were observed when the beams in these same series with different fabric densities were compared. The fully wrapped beams performed better than both the control and the beams with other retrofit patterns. The shear-deflection curves for the U-jacketed beams declined abruptly after peaking, an indication of brittle failure, while the curves for the completely wrapped beams showed greater ductility.
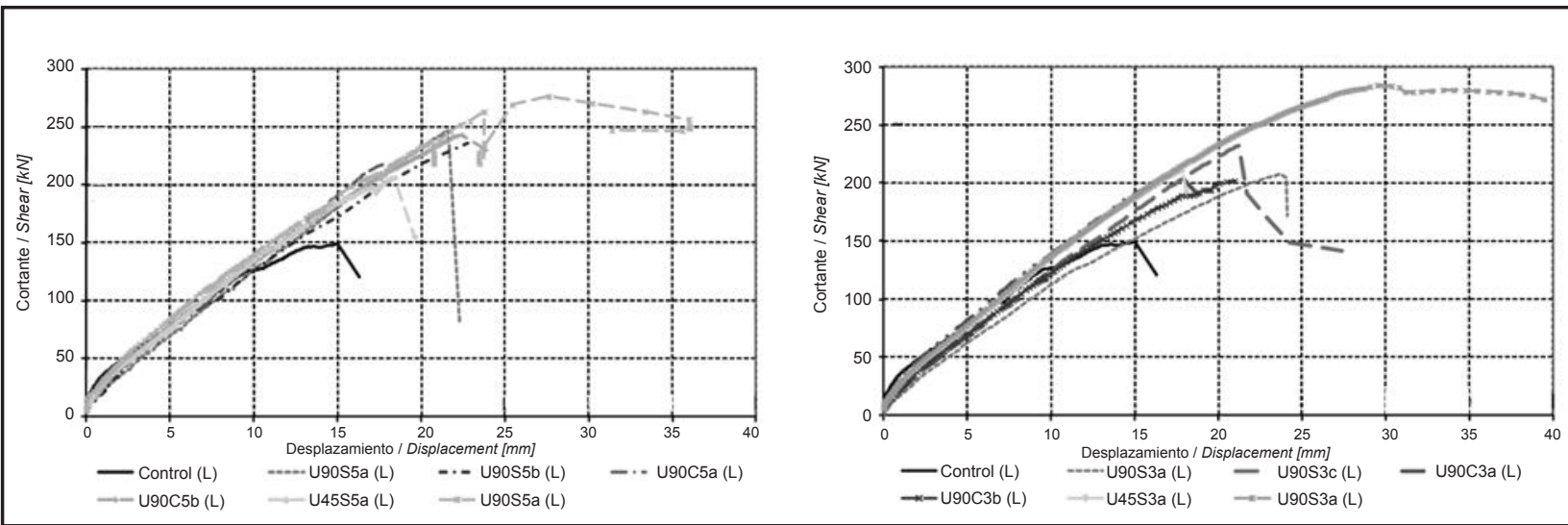

Figura 5. Cortante-flecha en centro de vano de vigas largas. Refuerzos de 530 y $300 \mathrm{~g} / \mathrm{m}^{2}$. Figure 5. Shear-deflection at mid-span in long beams: $530-$ and $300-\mathrm{g} / \mathrm{m}^{2} \mathrm{FRP}$ fabric.
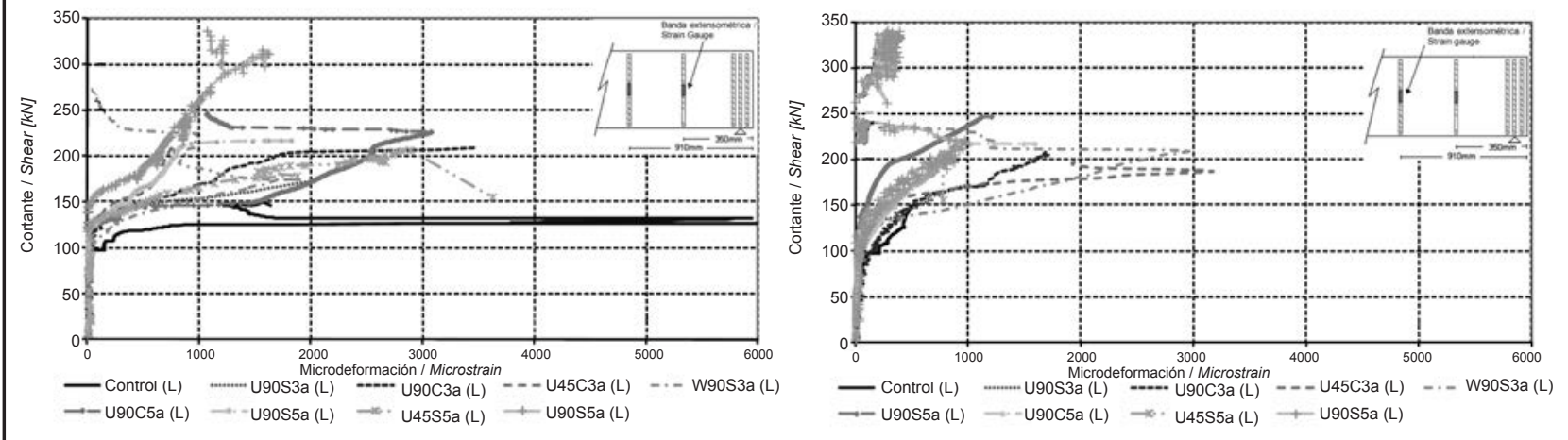

Figura 6. Vigas largas: deformaciones en el estribo más cercano y más alejado al apoyo. Figure 6. Long span trials: strain on the stirrup closest to and farthest from the support.

En la figura 6 se presentan las curvas cortante-deformación de las vigas largas obtenidas de las bandas extensométricas colocadas en los estribos como el promedio del par de bandas en cada cara. Tanto en la viga de control como en las vigas reforzadas con FRP los estribos de acero empiezan a desarrollar deformaciones solo a partir de la aparición de la primera fisura de cortante en el hormigón. Tomando el valor medio obtenido para los ensayos con luz larga y corta, se tiene que para la viga de control,
Figure 6 shows the shear stress-shear strain curves for the beams plotted from the values gathered by the strain gauges placed in the stirrups, taking the mean of the readings for each pair of gauges. No strain was recorded in the steel stirrups in either the control or the beams retrofitted with FRP until the first shear crack appeared in the concrete. According to the mean value obtained in the long and short span trials, the control beam began to develop strain at a mean shear of $90 \mathrm{kN}$, which is consistent with 
los estribos comienzan a desarrollar deformaciones a un cortante medio de $90 \mathrm{kN}$ el cual se compara bien con el valor aproximado de $85 \mathrm{kN}$ para el cual se detecta la primera fisura de cortante en la viga de control. Para las vigas reforzadas con FRP los estribos comienzan a desarrollar deformaciones a un cortante entre 110 y $130 \mathrm{kN}$. La magnitud de las deformaciones medidas está altamente influenciada por la posición de la banda extensométrica respecto a la fisura de cortante.

En la figura 7 se puede observar que a excepción de las vigas con configuración W90S, el estribo más cercano al apoyo es cortado por la fisura casi a la mitad de su altura, la cual coincide con la posición de la banda extensométrica y cuyas medidas muestran que se ha alcanzado el límite elástico de estos estribos antes de la rotura de la viga, por lo cual se tiene la completa contribución de estos $\left(\mathrm{V}_{\mathrm{s}}\right)$. La figura 8, muestra las deformaciones registradas por las bandas extensométricas en el FRP más cercanas a la fisura principal de cortante. Pueden ser tomadas como límite inferior de las deformaciones máximas obtenidas. the (approximately) $85 \mathrm{kN}$ at which the first shear crack appeared. In the FRP-wrapped beams, strain was first recorded at shear stress of 110 to $130 \mathrm{kN}$. The magnitude of the strain measured was highly affected by the position of the strain gauge with respect to the shear crack.

Figure 7 shows that except in the W90S beams, the crack cut across the stirrup closest to the support at nearly midheight, concurring with the position of the strain gauge. The gauge readings showed that the yield strength of these stirrups was reached before the beam failed, providing information on their total contribution $\left(V_{s}\right)$. Figure 8 shows the strain recorded by the gauges in the FRP closest to the main shear crack. These values may be taken as the lower limit of the peak strain obtained.

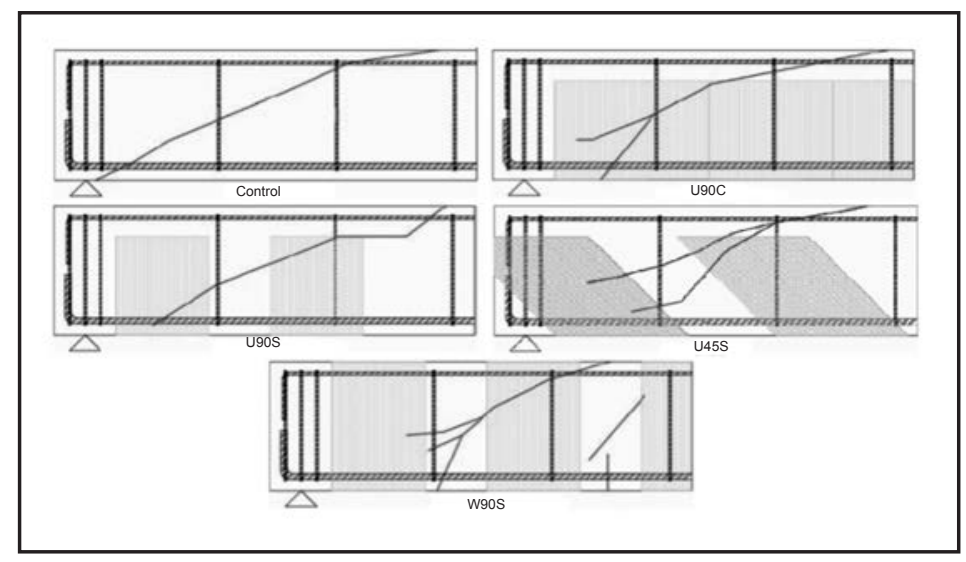

Figura 7. Patrón de fisuración.

Figure 7. Cracking pattern.

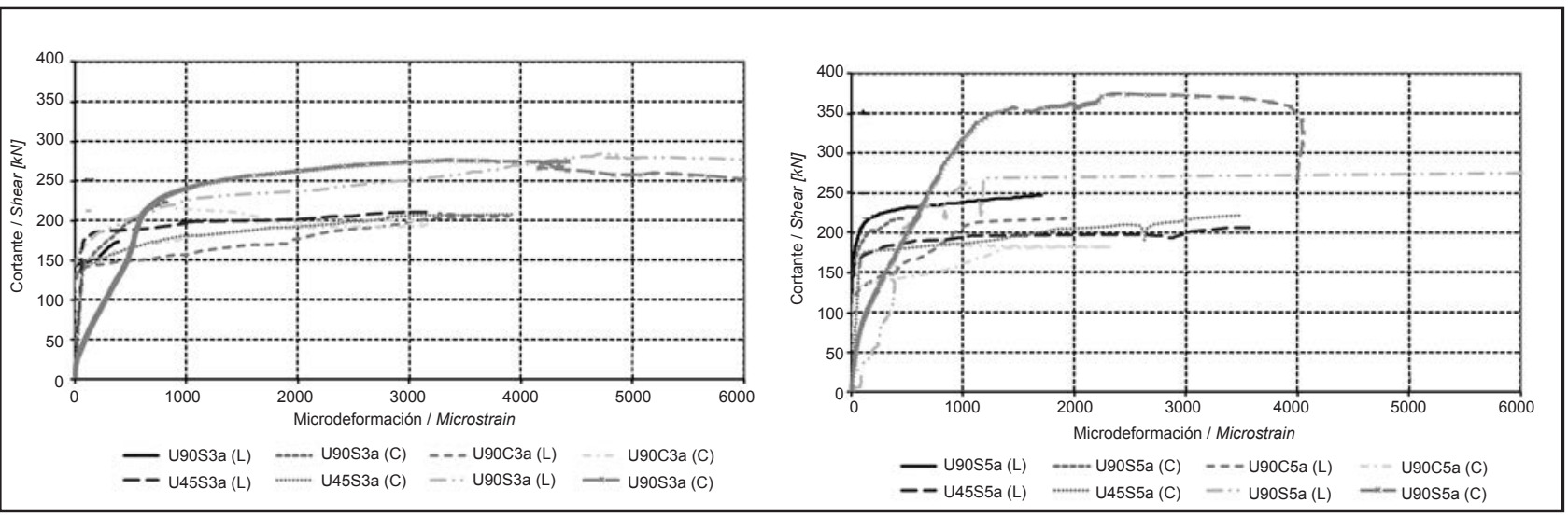

Figura 8. Deformaciones máximas en el FRP. Refuerzo de 300 y $530 \mathrm{~g} / \mathrm{m}^{2}$.

Figure 8. Peak strain in the FRP: $300-$ and $530-\mathrm{g} / \mathrm{m}^{2}$ FRP fabric. 
Tabla 4 / Table 4

Contribución a cortante del refuerzo externo con láminas de CFRP. CFRP sheet contribution to shear strength.

\begin{tabular}{|c|c|c|c|c|c|c|c|c|c|}
\hline \multirow{2}{*}{ Viga / Beam } & \multirow{2}{*}{$\begin{array}{c}\text { Prom I } \\
\text { Mean } V_{\text {exp }}\end{array}$} & \multicolumn{2}{|c|}{ Fib } & \multicolumn{2}{|c|}{ Teng et al. } & \multicolumn{2}{|c|}{ CNR } & \multicolumn{2}{|c|}{$\mathrm{ACl}$} \\
\hline & & $\mathrm{V}_{\mathrm{T}}[\mathrm{kN}]$ & $V_{\text {exp }} / V_{T}$ & $\mathrm{~V}_{\mathrm{T}}[\mathrm{kN}]$ & $V_{\text {exp }} / V_{T}$ & $\mathrm{~V}_{\mathrm{T}}[\mathrm{kN}]$ & $V_{\text {exp }} / V_{T}$ & $\mathrm{~V}_{\mathrm{T}}[\mathrm{kN}]$ & $V_{\text {exp }} / V_{T}$ \\
\hline U90S5-a & 78.82 & 126.21 & 0.62 & 42.82 & 1.84 & 67.46 & 1.17 & 70.97 & 1.11 \\
\hline U90S5-b & 90.70 & 113.81 & 0.80 & 39.09 & 2.32 & 56.84 & 1.60 & 59.01 & 1.54 \\
\hline U90C5-a & 71.87 & 135.49 & 0.53 & 47.01 & 1.53 & 86.47 & 0.83 & 89.87 & 0.80 \\
\hline U90C5-b & 102.13 & 131.61 & 0.78 & 45.73 & 2.23 & 81.79 & 1.25 & 85.34 & 1.20 \\
\hline U45S5 & 69.45 & 142.95 & 0.49 & 52.77 & 1.32 & 125.58 & 0.55 & 62.69 & 1.11 \\
\hline W90S5 & - & 183.90 & - & 206.00 & - & 86.82 & - & 122.08 & - \\
\hline U90S3-a & 75.31 & 80.95 & 0.93 & 28.93 & 2.60 & 36.72 & 2.05 & 36.57 & 2.06 \\
\hline U90S3-b & 83.38 & 83.92 & 0.99 & 29.88 & 2.79 & 39.42 & 2.12 & 39.00 & 2.14 \\
\hline U90S3-c & 65.47 & 90.95 & 0.72 & 32.02 & 2.04 & 45.55 & 1.44 & 45.02 & 1.45 \\
\hline U90C3-a & 68.51 & 117.12 & 0.58 & 41.30 & 1.66 & 79.58 & 0.86 & 78.90 & 0.87 \\
\hline U90c3-b & 59.24 & 117.12 & 0.51 & 41.30 & 1.43 & 79.58 & 0.74 & 78.90 & 0.75 \\
\hline U45S3-a & 67.98 & 98.28 & 0.69 & 37.58 & 1.81 & 76.35 & 0.89 & 36.57 & 1.86 \\
\hline U45S3-b & 64.97 & 114.23 & 0.57 & 42.38 & 1.53 & 99.47 & 0.65 & 47.83 & 1.36 \\
\hline W90S3-a & 186.03 & 130.89 & 1.42 & 127.87 & 1.45 & 58.5 & 3.18 & 73.33 & 2.54 \\
\hline W90s3-b & 150.01 & 130.96 & 1.15 & 127.87 & 1.17 & 58.56 & 2.56 & 73.33 & 2.05 \\
\hline Promedio / Mean & 88.13 & 115.32 & 0.77 & 52.61 & 1.84 & 70.85 & 1.42 & 62.67 & 1.49 \\
\hline COV & & & 0.35 & & 0.27 & & 0.56 & & 0.38 \\
\hline
\end{tabular}

* Fallo por flexión. / *Bending-induced failure.

En las vigas reforzadas con configuración en $U$, fallo por delaminación, las deformaciones mayores que se presentan son del 0,4\%, aproximadamente un tercio de la capacidad de deformación del tejido de fibras de carbono según los fabricantes. En las vigas con la sección completamente envuelta se alcanzan deformaciones superiores al 0,8\%, aproximadamente dos tercios de la deformación máxima de las fibras, por rotura del CFRP en las esquinas con concentración de tensiones. Es de notar que esta fracción de la deformación de rotura no tiene relación con el valor del coeficiente parcial necesario para pasar de los valores característicos de rotura del CFRP a los valores de cálculo.

Comparando las mediciones en los cercos y en el CFRP se observa que para las vigas reforzadas en $U$, cuando aparecen las primeras fisuras de cortante, los estribos entran primero en carga registrando deformaciones a una tasa de crecimiento constante. Un poco más tarde el FRP entra en carga deformándose rápidamente hasta alcanzar deformación similar a la de los estribos. A partir de ese punto, ambos refuerzos registran similares deformaciones aunque a una tasa mayor.

En la sección completamente envuelta (W), los estribos se empiezan a deformar primero, pero no se presenta acoplamiento de deformaciones entre estribos y FRP ya que el FRP empieza a tomar esfuerzos cortantes a altas deformaciones de los estribos, los cuales no tardan en alcanzar límite elástico, lo que supone que el aumento en el esfuerzo cortante es resistido únicamente por el FRP, llegándose a deformaciones mayores que en el otro tipo de refuerzo.
In the U-jacketed beams, where failure was due to debonding, the highest strain was $0.4 \%$, approximately one-third of the manufacturer's specified ultimate strain capacity for the fabric. In the fully wrapped beams, strain values of over $0.8 \%$, or approximately two thirds of the ultimate strain for the fibres, were recorded when the CFRP failed at the corners where stress converged. Note that this fraction of the failure strain is unrelated to the partial factor required to calculate CFRP design failure from its characteristic failure value.

A comparison of the readings in the ties and the CFRP revealed that in the U-jacketed beams initial stirrup loading concurred with the appearance of the first shear cracks, after which the strain values rose at a constant rate. The FRP fabric was loaded somewhat later, with strain appearing and quickly rising to approximately the values observed in the stirrups. Thereafter, the strain recorded in both elements was similar, although it rose at a higher rate.

In the fully wrapped $(W)$ beam, strain appeared first in the stirrups, but strain coupling between the stirrups and the FRP was not observed. Indeed, shear stress first appeared in the fabric at higher strain values than in the stirrups, which reached their yield stress very quickly. In other words, the increase in shear stress was resisted solely by the FRP, which attained higher strain here than in the $U$-jacketed beams. 


\subsection{Comparación de los resultados con las guías}

Con el fin de valorar los resultados obtenidos en este programa de ensayos, la Tabla 4 presenta los valores experimentales del aporte a cortante hecho por el refuerzo externo, obtenidos de restar del cortante alcanzado por las vigas reforzadas con FRP el cortante alcanzado por la viga de control (sin FRP), y los valores teóricos dados por los modelos del fib (1), Teng et al. (8), CNR (3) y ACI (5).

Debido a la diferencia en la calidad del hormigón, se hace una homogenización de los mismos asumiendo que hay una viga de control para cada caso, cuya resistencia es obtenida multiplicando el valor del cortante de la viga de control por la relación entre la resistencia del hormigón de la viga a homogenizar $f_{c m, x}$ y la viga de control $f_{c m, p r}$ elevados a la potencia de $1 / 3$ i.e. $\left[\left(f_{c m, x}\right) 1 / 3 /\left(f_{c m, p}\right) 1 / 3\right]$. Lo anterior de acuerdo con las especificaciones dadas en el Eurocódigo 2 (22) y EHE (23).

En dicha tabla, los valores experimentales son comparados con los valores teóricos a través de la relación $V_{\text {exp }} / V_{T I}$ acompañado de sus principales medidas estadísticas descriptivas. De los resultados obtenidos, se puede observar que para el caso de refuerzo en $\mathrm{U}$ (o de fallo por delaminación), el modelo de la fib presenta los valores de cortante teórico más elevados, sobrepasando incluso el valor experimental. Por su parte con los modelos de CNR, ACI y Teng et al., se obtienen en promedio las predicciones más seguras pero con un alto grado de dispersión en sus resultados. Como caso particular los valores dados por el CNR, cuando el refuerzo es en $U$ a $45^{\circ}$, se elevan considerablemente debido a la forma como este modelo define la separación entre láminas. En cualquier caso el modelo de Teng et al., resulta ser el más conservador.

Cuando se envuelve completamente la sección, los modelos de la fib y de Teng et al., presentan los valores que mejor se ajustan a los resultados experimentales, en contraposición con los modelos del CNR y ACI que presentan las predicciones más bajas. Para el caso del $\mathrm{ACI}$ se debe a que la deformación efectiva está limitada al 0,004 con el fin de asegurar el mecanismo de engranamiento de áridos y mantener la integridad de la estructura. Cabe notar que el modelo del fib limita esta deformación al $0,6 \%$ en caso de ser necesario que se active dicho mecanismo (restricción no tomada en este trabajo). Por su parte el modelo del CNR parece no tratar adecuadamente este caso donde las predicciones resultan ser incluso menores que para las configuraciones de $\mathrm{U}$ continuo o $\mathrm{U}$ con separación a $45^{\circ}$.

Como se ha indicado, muchos investigadores han resaltado la importancia de la interacción entre los cercos internos y el refuerzo externo, aunque ninguna de las

\subsection{Comparison of findings with guide specifications}

Table 4 gives the experimental values for the strengthening contribution to ultimate shear strength obtained by subtracting the shear found for the control (with no FRP) from the value attained by the FRP-strengthened beams. The table also lists the theoretical values found with the fib (1), Teng et al. (8), CNR (3) and ACI (5) models.

The formula set out in Eurocode 2 (22) and Spanish structural concrete code EHE (23) was applied to account for the differences in concrete quality. More specifically, the values were normalised by assuming the existence of a control beam for each case, whose shear strength was found by multiplying the ultimate shear for the actual control by the ratio between the concrete strength in the beam to be normalised, $f_{c m, x}$ and in the control beam, $f_{c m, p r}$ raised to a power of 1/3: i.e., $\left[\left(f_{c m, x}\right) 1 / 3 /\left(f_{c m, p}\right) 1 / 3\right]$.

The experimental values are compared to the theoretical values in the table in the column headed $V_{\text {exp }} / V_{T}$ ratio. The chief descriptive statistical parameters are also given. The findings show that for U-jacketed beams (detachment failure), the fib model delivered the highest theoretical shear values, which were even higher than the experimental value. The CNR, ACI and Teng et al. models, in turn, delivered the safest mean predictions, but their results were widely scattered. In the specific case of U-jacketing at 450, the CNR values were substantially higher than in the other models due to the way the former defines intersheet spacing. In any event, the Teng et al. model proved to be the most conservative.

When the beam was fully wrapped, the values with the best fit to the experimental findings were found with the fib and Teng et al. models, while the CNR and ACI models predicted the lowest values. In the ACI approach this was because effective stress is limited to 0.004 to ensure aggregate interlock and maintain structural integrity. The fib model, in turn, limits strain to $0.6 \%$ if the aforementioned mechanism needs to be activated (that constraint was not applied in the present study). The CNR approach appears to model this case rather unsuitably, for its predictions for fully wrapped beams were even lower than for the continuous and spaced U-jacketed beams with FRP placed at a $45^{\circ}$ angle.

As noted earlier, many researchers have stressed the importance of the interaction between internal ties and external strengthening, although none of the existing 
guías existentes la considera. Recientemente Chen et al. (19) proponen dos factores de corrección para la contribución del acero y el FRP con base en sus tensiones efectivas, así [2]: guides addresses this question. Chen et al. (19) recently proposed two correction factors for the contributions made by the steel and FRP, based on their effective stress values, i.e. [2]:

$$
\mathrm{V}_{\mathrm{T}}=\mathrm{V}_{\mathrm{C}}+\mathrm{K}_{\mathrm{S}} \mathrm{V}_{\mathrm{S}}+\mathrm{K}_{\mathrm{f}} \mathrm{V}_{\mathrm{f}}
$$

Con $\mathrm{Ks}=\sigma_{\mathrm{s}} / \mathrm{f}_{\mathrm{y}}$ y $\mathrm{K}_{\mathrm{f}}=\sigma_{\mathrm{f}} / \mathrm{f}_{\mathrm{fe}}$, pero no proponen expresión alguna para su cálculo. Mofidi y Chaallal (26), propone un coeficiente de corrección $\beta_{c}$ (equivalente a $K_{f}$ ) para el FRP [3]:

$$
\beta_{c}=\left\{\begin{array}{l}
\frac{0.6}{\sqrt{\rho_{s} E_{s}+\rho_{f} E_{f}}} \\
\frac{0.43}{\sqrt{\rho_{s} E_{s}+\rho_{f} E_{f}}}
\end{array}\right.
$$

De forma similar y con base en los resultados obtenidos en nuestro programa experimental se propone la siguiente expresión para el cálculo de $\mathrm{K}_{\mathrm{s}}$, cuando el refuerzo se realiza en configuración en U. Un estudio detallado de ese aspecto puede verse en (27). Así [4]:

$$
\mathrm{K}_{s}=\left\{\begin{array}{rr}
\frac{0.73}{\left(\rho_{s} E_{s}+\rho_{f} E_{f}\right)^{0.70},} & \rho_{s} E_{s}+\rho_{f} E_{f}<0.64 \\
1, & \rho_{s} E_{s}+\rho_{f} E_{f} \geq 0.64
\end{array}\right.
$$

where $K s=\sigma_{s} / f_{y}$ y $K_{f}=\sigma_{f} / f_{\text {fer }}$ but they put forward no expression to calculate that value. Mofidi and Chaallal (26) proposed a correction factor, $\beta_{c}$ (equivalent to $K_{f}$ ), for the FRP [3]:

$$
\begin{aligned}
& \text { Configuración U / U - jacketing } \\
& \text { Pegado lateral / Side bonding }
\end{aligned}
$$

Similarly, and based on the results obtained here, the following expression is proposed for calculating $K_{s}$ in $U$-jacketed members. A detailed description of its formulation can be found in Alzate et al. (27), [4].

\section{CONCLUSIONES}

Son múltiples los factores que influyen en el comportamiento de vigas de HA reforzadas a cortante con FRP y que originan una gran dispersión en los valores, por lo que las siguientes conclusiones deben considerarse como conclusiones parciales inherentes a este trabajo.

- El refuerzo externo de elementos de HA con láminas de FRP se presenta como una alternativa viable a los métodos convencionales en la rehabilitación de estructuras.

- Los modelos de cálculo existentes referidos a cortante resultan ser variables y controvertidos.

- El acercamiento de la analogía de la celosía se muestra adecuado para el cálculo del aporte a cortante hecho por el FRP.

- El refuerzo externo con FRP puede incrementar significativamente la capacidad a cortante de una viga de HA con baja cuantía de acero transversal. Para este programa de ensayos, el incremento en la capacidad a cortante en las vigas reforzadas en U fue entre $31 \%$ y $51 \%$ dependiendo de la configuración y cantidad de refuerzo y de aproximadamente el doble para las vigas con la sección completamente envuelta con respecto a la viga de control.

\section{CONCLUSIONS}

Due to the many factors involved, the values measuring the performance of RC beams with FRP shear strengthening are widely scattered. The conclusions drawn from the above results must therefore be regarded as partial only and confined to the present study.

- Externally bonding FRP sheets to RC members is a viable alternative to the conventional methods used in structural rehabilitation.

- The existing theoretical models for shear adopt different approaches, noneof which hasbeen universallyaccepted.

- Truss analogy proves to be the most suitable manner to calculate the contribution made by FRP to shear strength.

- External strengthening with FRP can significantly raise the shear capacity of an $R C$ beam with a small transverse steel ratio. In the present study, depending on fabric density and placement pattern, the shear strength of U-jacketed beams was 31 to $51 \%$ higher than in the unstrengthened control, while strength in wholly wrapped beams doubled the value observed for the control. 
- No se presentó un incremento significativo en la rigidez de las vigas reforzadas con CFRP respecto a la viga de control.

- Para las vigas reforzadas en $\mathrm{U}$, el modo de fallo fue en todos los casos por delaminación con desprendimiento del recubrimiento de hormigón. Para el caso de las vigas con la sección completamente envuelta el fallo se produjo por rotura del tejido por concentración de tensiones en las esquinas o por fallo a flexión de la viga.

- Las predicciones obtenidas con el modelo del CNR, para las vigas reforzadas con la sección completamente envuelta, presentan valores bastante conservadores.

- El aumento de carga de rotura no es proporcional al aumento en la cantidad de fibra.

- Ninguno de los modelos propuestos puede considerarse adecuado como modelo general para la predicción del aporte a cortante hecho por el FRP.

Son necesarios más estudios experimentales y teóricos para entender la interacción entre el FRP y el acero de refuerzo transversal, para el caso de cuantías normales y altas de acero.

\section{AGRADECIMIENTOS}

Este trabajo forma parte de los proyectos de investigación del Plan Nacional BIA2007-67790-C02-01 y BIA201020234-C03-03 financiados por el Ministerio de Ciencia e Innovación. A su vez, dentro de este trabajo se ha desarrollado una beca de Formación de Personal Investigador (BES2006-12211) otorgada a Albert Alzate y financiada por el Ministerio de Ciencia e Innovación, y una beca JAE-Predoc otorgada a Daniel Cisneros (JAEPre09-01914) correspondiente al Programa Junta para la Ampliación de Estudios del CSIC y cofinanciada por el Fondo Social Europeo. Finalmente, agradecer a SIKA y BASF el suministro de todo el material de refuerzo y en particular a Neus Borrell por el interés y soporte técnico proporcionado.
- Beam stiffness was not observed to be significantly greater in the retrofitted beams than in the control.

- In the U-jacketed beams, failure was due in all cases to debonding, with detachment of the concrete cover. In the fully wrapped beams, failure was due either to beam bending failure or to fabric rupture induced by the convergence of stress at the corners.

- $\quad$ The CNR model predictions for fully wrapped beams were fairly conservative.

- The rise in the ultimate load was not proportional to the rise in fibre density used.

- None of the models proposed can be regarded as suitable for general use to predict the portion of shear strength attributable to FRP.

More experimental and theoretical study is needed to understand the reaction between FRP and the transverse steel reinforcement in members with standard and high steel ratios.

\section{ACKNOWLEDGMENTS}

This study forms part of National Research Plan projects BIA2007-67790-C02-01 and BIA2010-20234-C03-03, funded by the Spanish Ministry of Science and Innovation. Albert Alzate participated in the study under a Ministry of Science and Innovation research personnel training grant (BES2006-12211), while Daniel Cisneros benefited from a Post-graduate Studies Council scholarship (JAEPre09-01914) co-funded by the Spanish National Research Council and the European Social Fund. The authors wish to thank SIKA and BASF for furnishing the FRP material used, and Neus Borrell for her industrious technical support.

\section{BIBLIOGRAFÍA / BIBLIOGRAPHY}

(1) Federation Internationale du Béton (FIB): Externally bonded FRP reinforcement for RC structures, Technical Report, Task Group 9.3, Bulletin 14, Lausanne, Switzerland, 2001, pp. 59-68.

(2) CAN/CSA. Design and construction of building component with fiber-reinforced polymer. S806-02, Canadian StandardsAssociation, Rexdale, Canada.

(3) Consiglio Nazionale delle Ricerche, Istruzioni per la Progettazione, l'Esecuzione ed il Controllo di Interventi di Consolidamento Statico mediante I'utilizzo di Compositi Fibrorinforzati. Roma, 13 luglio 2004, p. 164.

(4) CIDAR. Design guideline for RC structures retrofitted with FRP and metal plates: Beams and slabs. Draft 3 - Submittedtostandards Australia, CIDAR/CBIR, Australia, 2006.

(5) ACI 440.2R-08. Guide for the design, and construction of externally bonded FRP systems for strengthening of concrete structures, Reported by ACI Committee 440, 2008, pp. 32-34.

(6) Triantafillou, T.: "Shear strengthening of reinforced concrete beams using epoxy-bonded FRP composites", ACI Structural Journal, Vol. 95, no 2 (1998), pp. 107-115. 
(7) Khalifa, A.; Gold, W.; Nanni, A.; Abdel, A.: "Contribution of externally bonded FRP to shear capacity of RC flexural members", J. Compos. Constr.; vol. 2, no 4 (1998), pp. 195-202.http://dx.doi.org/10.1061/(ASCE)1090-0268(1998)2:4(195)

(8) Teng, J.; Chen, J.; Smith, S.; Lam, L.: FRP strengthened RC structures. UK, Wiley, 2002, pp. 245.

(9) Chen, J.; Teng, J.: "Shear capacity of FRP-strengthened RC beams: FRP debonding", Constr. Build. Mater. vol. 17, no 1 (2003), pp. $27-41$. http://dx.doi.org/10.1016/S0950-0618(02)00091-0

(10) Deniaud, C.; Cheng, R.: "Reinforced Concrete T-Beams Strengthened in Shear with FRP Sheets", J. Compos. Constr. vol. 7, n 2 (2003), pp. 302-310.

(11) Deniaud, C.; Cheng, R.: "Simplified Shear Design Method for Concrete Beams Strengthened with FRP Sheets", J. Compos. Constr. vol. 8, no 5 (2004), pp. 425-433. http://dx.doi.org/10.1061/(ASCE)1090-0268(2004)8:5(425)

(12) Pellegrino, C.; Modena, C.: "Fiber reinforced polymer shear strengthening of reinforced concrete beams: Experimental study and analytical modeling", ACI Structural Journal vol. 103, no 5 (2006), pp. 720-728.

(13) Ianniruberto, U.; Imbimbo, M.: "Role of fiber reinforced plastic sheet in shear response of reinforced concrete beams: experimental and analytical results", J. Compos. Constr. vol. 8, no 5 (2004), pp. 415-424. http://dx.doi.org/10.1061/(ASCE)1090-0268(2004)8:5(415)

(14) Carolin, A.; Täljsten, B.: "Theoretical study of strengthening for increased shear bearing capacity", J. Compos. Constr. vol. 9, no 6 (2005), pp. 497-506. http://dx.doi.org/10.1061/(ASCE)1090-0268(2005)9:6(497)

(15) Cao, S.; Chen, J.; Teng, J.; Hao, Z.: "Debonding in RC beams shear strengthened with complete FRP wraps", J. Compos. Constr. vol. 9, no 5 (2005), pp. 417-428. http://dx.doi.org/10.1061/(ASCE)1090-0268(2005)9:5(417)

(16) Ye, L.; Lum, X.; Chen, J.: "Design proposal for debonding strength of FRP strengthened RC beams in the Chinese Design Code", Proceedings of International Symposium on Bond Behaviour of FRP in Structures, Hong Kong, China (2005), pp. 55-62.

(17) Monti, G.; Liotta, M.: "Test and design equations for FRP strengthening in shear", Constr. Build. Mater., vol. 21 (2007), pp. $799-809$. http://dx.doi.org/10.1016/j.conbuildmat.2006.06.023

(18) Ahmad, S.; Shah, A.; Nawaz, A.; Salimullah, K.: "Refuerzo a cortante de ménsulas con polímeros reforzados con fibra de carbono (CFRP)", Mater. Construcc. vol. 60, no 299 (2010), pp. 79-97.

(19) Chen, M.; Teng, J.; Chen, J.; Rosenboom, O.: "Interaction between steel stirrups and shear-strengthening FRP strips in RC Beams", J. Compos. Constr. vol. 14, no 5 (2010), pp. 498-509. http://dx.doi.org/10.1061/(ASCE)CC.1943-5614.0000120

(20) Perera, R.; Arteaga, A.; de Diego, A.: "Artificial intelligence techniques for prediction of the capacity of RC beams strengthened in shear with external FRP reinforcement", Composite Structures, vol. 92 (2010), pp. 1169-1175. http://dx.doi.org/10.1016/j.compstruct.2009.10.027

(21) Perera, R.; Barchín, M.; Arteaga, A.; de Diego, A.: "Prediction of the ultimate strength of reinforced concrete beams FRP-strengthened in shear using neural networks", Composites: Part B, vol. 41 (2010), pp. 287-298. http://dx.doi.org/10.1016/j.compositesb.2010.03.003

(22) European Committee for Standardization, Eurocode 2: Design of Concrete Structures, Part 1: General rules and rules for buildings, 2004, pp. 225.

(23) EHE-08. Instrucción de Hormigón Estructural, Ministerio de Fomento, 2008.

(24) Comite Euro-International du Beton. CEB-FIP Model Code 1990. V1, 2003.

(25) Murphy, M.; Belarbi, A.; Kuchma, D.: "Shear design equations for concrete girders strengthened with FRP", The international conference on FRP composites in civil engineering (CICE). Beijing, China, vol. II (2010), pp.767-771.

(26) Mofidi, A.; Chaallal, O.: "Shear strengthening of RC beams with EBR-FRP - influencing factors and conceptual debonding model", J. Compos. Constr. vol. 15, no 1 (2011), pp. 62-74. http://dx.doi.org/10.1061/(ASCE)CC.1943-5614.0000153

(27) Alzate, A.; Arteaga, A.; de Diego, A.; Cisneros, D.; Perera, R.: "Experimental study on reinforced concrete beams externally shear strengthened with CFRP sheets", Constr. Build. Mater. Aceptado, en revisión. 